\title{
The saola or spindlehorn bovid Pseudoryx nghetinhensis in Laos
}

\author{
George B. Schaller and Alan Rabinowitz
}

\begin{abstract}
In 1992 the discovery of a new bovid, Pseudoryx nghetinhensis, in Vietnam led to speculation that the species also occurred in adjacent parts of Laos. This paper describes a survey in January 1994, which confirmed the presence of P. ngethinhensis in Laos, although in low densities and with a patchy distribution. The paper also presents new information that helps clarify the phylogenetic position of the species. The low numbers and restricted range of $\mathrm{P}$. ngethinhensis mean that it must be regarded as Endangered. While some admirable moves have been made to protect the new bovid and its habitat, more needs to be done and the authors recommend further conservation action.
\end{abstract}

\section{Introduction}

In May 1992 Do Tuoc and John MacKinnon found three sets of horns of a previously undescribed species of bovid in the Vu Quang Nature Reserve of west-central Vietnam (Stone, 1992). The discovery at the end of the twentieth century of a large new mammal in a region that had been visited repeatedly by scientific and other expeditions (Delacour and Jabouille, 1931; Legendre, 1936) aroused intense interest. Four subsequent Vietnamese surveys produced the remains of over 20 partial specimens of the bovid, which has been given the scientific name Pseudoryx nghetinhensis (Dung et al., 1993). One local name for the animal is saola, spindlehorn, because its long tapered horns resemble a weaver's spindle (Dung et al., 1994). Because all Vietnamese distribution records of saola were from the forests of the Annamite Mountain range along the Vietnam-Laos border, Dung et al. (1993) assumed that the species could also occur in Laos. The first evidence of saola in Laos was found by Robert Dobias who in early 1993 saw a set of horns at the village of Nakadok near the Vietnam border (Salter, 1993). The local people there knew the animal as saola or yang (not to be confused with yeang, the serow Naemorhedus sumatraensis, which is in size similar to the saola and also occurs in that area). Dung et al. (1994) refer to Pseudoryx as the Vu Quang ox, but, given the total range of the animal and its evolutionary affinities (see below), we prefer to call it by the descriptive local name 'saola'.

The village of Nakadok, where saola horns were found, lies at the end of the Nakai-Nam Theun National Biodiversity Conservation Area (NNTNBCA), which at $3500 \mathrm{sq} \mathrm{km}$ is the largest of 17 protected areas established by Laos in October 1993. Laos plans a major hydroelectric project on the Nam Theun, a river whose primary watershed is the Conservation Area. The dam will inundate some of the lowlands in the conservation area. During January 1994 we collaborated with the Department of Forestry, Lao People's Democratic Republic, in a survey of the status of large mammals in the region. During this survey we repeatedly found evidence of saola. A survey of this species outside the conservation area is planned for the near future. Here we present preliminary data that confirm the presence of saola in Laos and indicate that a breeding population with a fairly extensive distribution exists.

\section{Study methods}

We interviewed villagers and other local people about saola and walked about $415 \mathrm{~km}$ to 


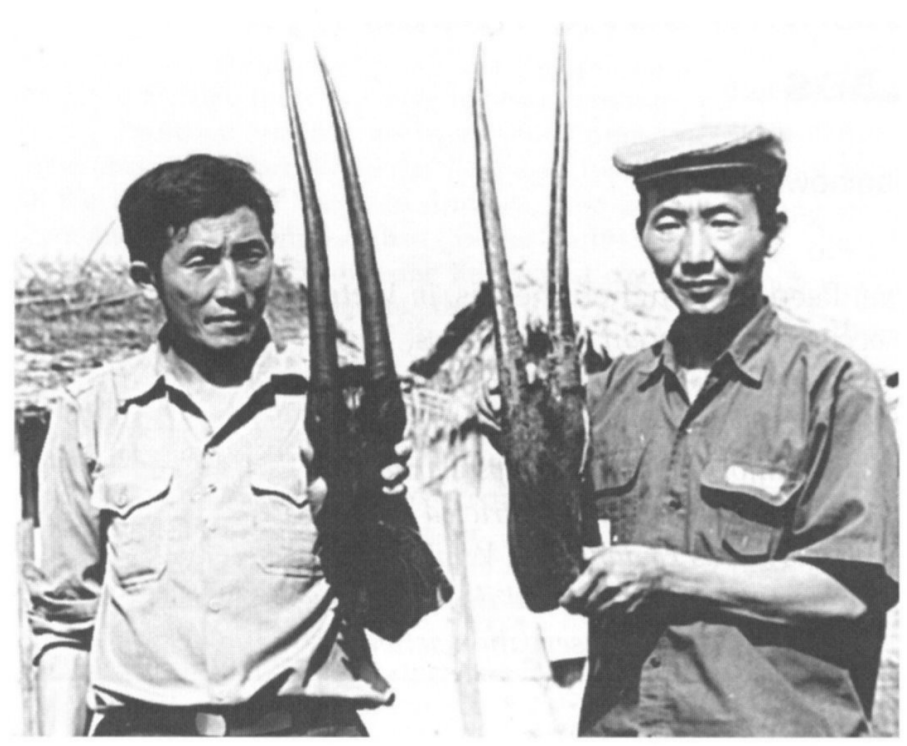

Two Hmong tribesmen at the village of Nape with the horns of a female saola (George B. Schaller). assess the relative abundance and distribution of large mammals in the Conservation Area. Local people living in or near the forest hunt and trap wildlife extensively, and this makes them usually reliable informants about the status of species within their area. The saola is encountered so infrequently and has such a distinctive appearance that hunters and others remember for years the location and the details of a killing or sighting. Because villagers usually consume all edible parts of a carcass, including the skin, and domestic pigs and dogs dispose of the bones, physical evidence of a killed saola does not persist for long; however, on occasion the horns, sometimes with a part of the skull, are nailed to a hut wall and these were measured. The horns of 10 saola, some attached to the top half of the skull, as well as the rotting hide and one hoof of an adult female were examined.

\section{Distribution}

The saola's known range in Vietnam extends from the Song $\mathrm{Ca}$ River at about $19^{\circ} 25^{\prime} \mathrm{N}$, $104^{\circ} 05^{\prime} \mathrm{E}$ south to about $18^{\circ} 05^{\prime} \mathrm{N}, 105^{\circ} 50^{\prime} \mathrm{E}$ along $225 \mathrm{~km}$ of the Annamite Mountains. It encompasses about $4000 \mathrm{sq} \mathrm{km}$ primarily of montane evergreen broad-leaved forest at 200-2000 m a.s.l. (Dung et al., 1993). The Laotian side of the Annamites has terrain and vegetation similar to that on the Vietnamese side, and the saola is probably found throughout that part as well; however, our work has so far confirmed the species only in the southern half (Figure 1). Vietnamese hunters commonly cross the border and some of the specimens examined by Dung et al. (1993) in Vietnam may have been killed in Laos. Villagers also informed us that they had sold their saola horns to Vietnamese.

Figure 1 shows 23 localities where local people sighted or killed saola; about half the records are from 1990 onward. The records cluster in or near the northern end of the conservation area, partly because our surveys were mostly done there and partly because the species appears to become scarcer to the south. For example, saola were once found around the village of Navang, but only one animal has been killed there in recent times, about 6 years ago. Visits to the south-eastern portion and along the southern boundary of the conservation area indicated that most villagers are unfamiliar with the saola or had heard of its occurrence to the north. We were told that saola tend to concentrate in certain 


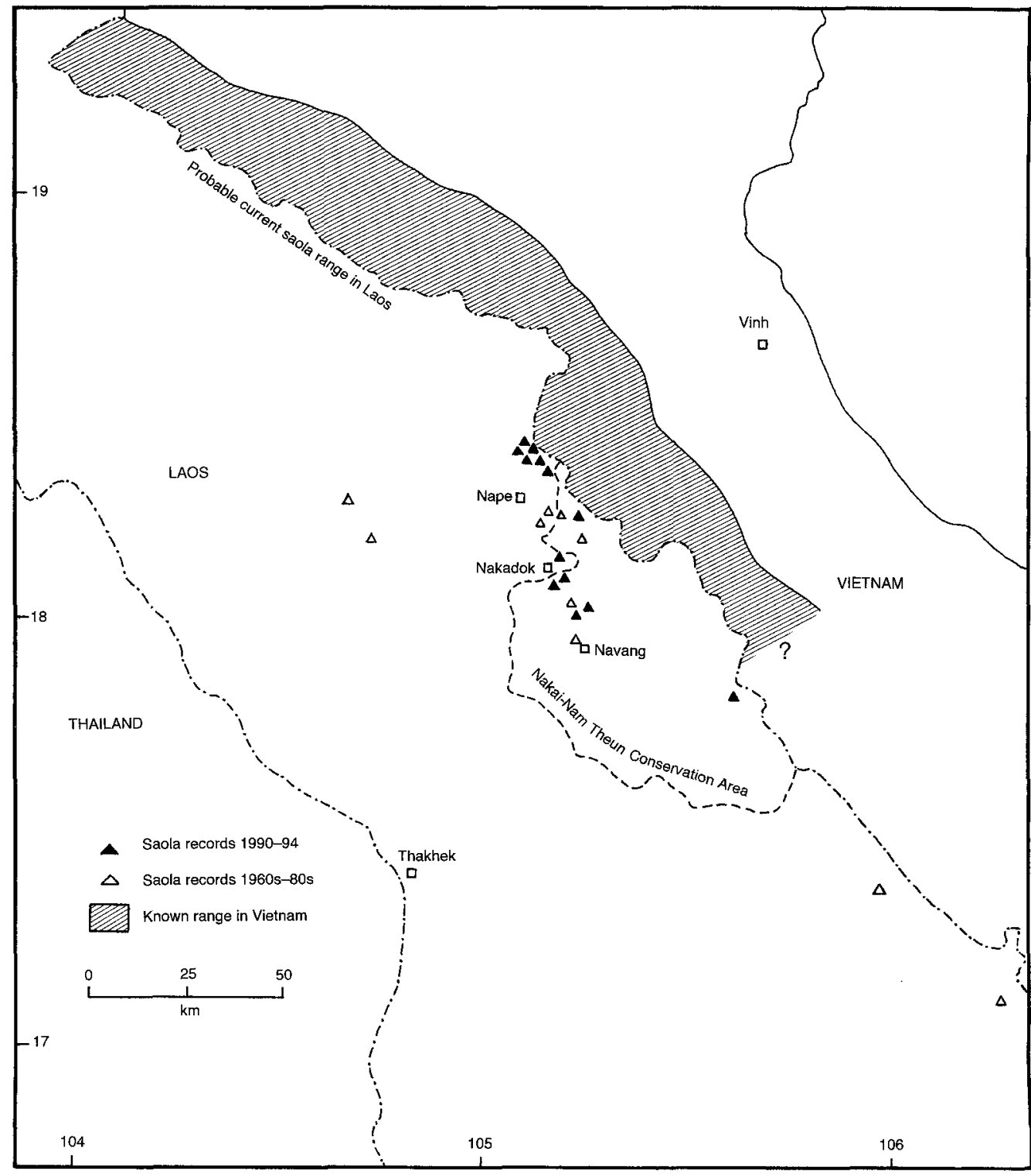

Figure 1. Distribution of saola or spindlehorn bovid in Laos and Vietnam. The data for Vietnam are based on the map in Dung et al. (1993).

localities, leaving others unoccupied. If so, pockets of animals may exist in the Conservation Area along the Vietnam border where villagers seldom go.

Most of the records come from steep but not precipitous mountains covered with a closed canopy of evergreen broad-leaved forest and (C) 1995 FFPS, Oryx, Vol 29, No 2 an understorey of saplings, bamboo, and palms. About half of the records were at $500-1000 \mathrm{~m}$ a.s.l. and the rest up to about 1400 $m$. Although the species is usually encountered in primary forest, it may frequent secondary growth. Dogs flushed a female with young from a thicket near Nakadok and 


\begin{tabular}{llll}
\hline Sex* & $\begin{array}{l}\text { Length of } \\
\text { longest horn } \\
(\mathrm{cm})\end{array}$ & $\begin{array}{l}\text { Circumference } \\
\text { of horn base } \\
(\mathrm{cm})\end{array}$ & $\begin{array}{l}\text { Width between } \\
\text { horn tips } \\
(\mathrm{cm})\end{array}$ \\
\hline Female & 9.5 & 6.4 & 6.8 \\
Male & 18.8 & 8.4 & - \\
Male & 36.2 & 12.2 & 11.0 \\
Male & 39.5 & 12.1 & 8.2 \\
Male & 45.5 & 13.0 & 6.0 \\
Female & 45.0 & 11.8 & - \\
Female & 45.1 & 11.0 & 3.5 \\
Female & 50.4 & 11.2 & 11.5 \\
Unknown & 42.6 & 11.2 & 8.7 \\
Unknown & 49.5 & 10.8 & 18.4 \\
\hline
\end{tabular}

Table 1. Horn measurements of saola

* The sex of specimens was determined through questioning either the hunter who killed the animal or a second party who had direct knowledge of the kill. Our questioning revealed that the first two animals in this list were subadults and the rest were presumed adults.

villagers clubbed the young to death.

Two old records are from a considerable distance west of the conservation area and two are to the south. These four are from karst, a rugged topography of Silurian limestone consisting of great grey slabs of rock, serrated ridges and sheer isolated domes with forest draping the base and the ravines. Karst at low altitudes tends to be dry, covered with semideciduous or deciduous forest and scrub, but high up on slopes of moderate steepness there are tracts of evergreen broad-leaved forests that saola seem to prefer. The two western records are not in the Annamites but on isolated karst ranges. Karst is widespread in this part of Laos and it is possible that saola were once or are still found there in isolated populations.

Our preliminary survey suggests that in Laos the saola has a patchy distribution and exists at low densities but that its geographical range is at least as extensive as in Vietnam.

\section{Physical characteristics of saola}

Based on DNA analysis, Dung et al. (1993) placed the saola in the subfamily Bovinae*, which includes wild cattle and buffalo (tribe Bovini), spiral-horned antelopes (Tragelaphini) and the nilgai antelope (Boselaphini). Dung et al. $(1993,1994)$ provide a partial description of the saola. On the basis of examining fragmentary specimens we provide additional information that helps to clarify the phylogenetic position of the species within the subfamily.

The saola may weigh up to an estimated 100 $\mathrm{kg}$ and reach a shoulder height of $80-90 \mathrm{~cm}$ (Dung et al., 1993). It has a compact neck and body, but the head is rather delicately shaped with a narrow muzzle and arched nasal bones. The body form is reminiscent of duikers Cephalophus spp., apparently adapted to moving through dense cover.

The pelage is generally a glossy deep chestnut to black, with the legs the darkest, and a thin dark stripe traces the back from the nape to the short tail (Dung et al., 1993). However, the hide of one female we examined was mostly dull dark brown except for the lower belly and inside of the thighs, which were pale grey to white. Several light markings are conspicuous on the saola's hide (Anon., 1993), including a broad white band above each hoof

\footnotetext{
* Since this paper was submitted, a 1994 paper by H. Thomas (Anatomie crânienne et relations phylogénétiques du nouveau bovidé [Pseudoryx nghetinhensis] découvert dans la cordillère annamitique au Vietnam. Mammalia, 58 (3), 453-481) was published. On the basis of a morphological study it concluded that the saola is most closely related not to the Bovinae but to the Caprinae. Editor
} 
and a variable pattern of white around the tip of the muzzle and sides of face, most prominently a stripe above each eye. The hooves of one female were dark grey, blunt-tipped and 6 $\mathrm{cm}$ long, in size and shape similar to those of the lowland anoa Bubalus depressicornis of Sulawesi, as pictured by van Strien (1983).

The horns are thin, almost smooth and nearly straight but with a slight backward curve. The longest reported set of horns measured $52 \mathrm{~cm}$ (Dung et al., 1993) but those of most adults are about $40-50 \mathrm{~cm}$ long (Table 1 ). The internal width between the base of the horns averages $3.1 \mathrm{~cm}(2.8-3.6 ; n=5)$, whereas the width between horn tips ranges from $3.5-18.4 \mathrm{~cm}$ (Table 1), indicating that animals have almost parallel to moderately diverging horns. One villager told us that he had seen an animal with crossed horn tips. Both the horn sheaths and horn cores are without keel and slightly oval in cross-section, the narrow part anteriorly. The circumference at the base of the horn sheath varies from $11.0-13.0 \mathrm{~cm}$ (Table 1). Most horns have slight to moderately heavy corrugations within $2-4 \mathrm{~cm}$ of the base. In two of six adult horns (one female, one of unidentified sex) the basal $5.2-5.4 \mathrm{~cm}$ were thick, coarsely corrugated and bruised before constricting to a smooth shaft. One young, estimated to be about 4 months old, had horns $9.5 \mathrm{~cm}$ long with a small bulge at the base and a second bulge slightly higher. The horn cores of adult saola are exceptionally long, 82 per cent of the length of the horns in one animal and 88 per cent in another. The saola's generic name Pseudoryx refers to the superficial resemblance of the horns to those of Oryx (subfamily Hippotraginae), but their greatest similarity, except in length, lies with two other members of its own subfamily. The mountain anoa Bubalus quarlesi has smooth, rounded horns, $15-20 \mathrm{~cm}$ long (Nowak, 1991) and the nilgai Boselaphus tragocamelus has smooth, slightly forward-curving horns about $20 \mathrm{~cm}$ long and triangular at the base (Lydekker, 1924).

The saola has a large fossa $-6 \mathrm{~cm}$ long and 3 $\mathrm{cm}$ wide in one subadult male - on the lachrymal bone. This fossa marks the site of a preorbital gland (Dung et al., 1993). Preorbital

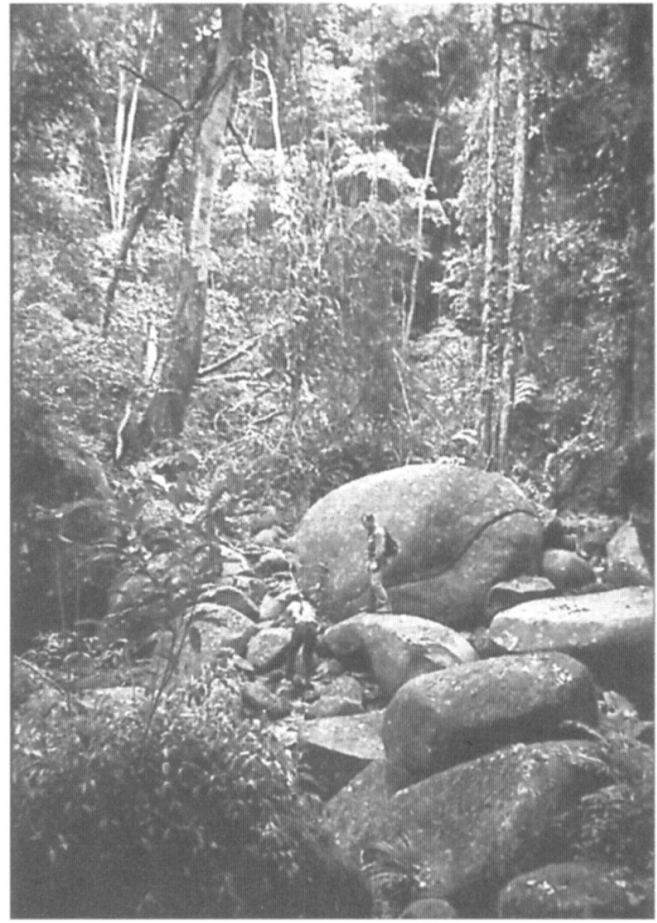

A boulder-strewn stream in broad-leaved evergreen forest of the Annamite Mountains where villagers killed a saola a few days previously (George B.

Schaller).

glands are absent in the Bovini and Tragelaphini but they occur in one other member of the subfamily, the nilgai.

Most Bovinae are sexually dimorphic in that adult males have a larger body, longer and more massive horns, and often also a darker or more strikingly marked pelage than the females; indeed, the females of nilgai and some spiral-horned antelopes are hornless (Estes, 1991). Any dimorphism in saola appears to be minor with, for example, the basal horn circumference of males possibly slightly greater than that of females (Table 1), as a result of which male horns taper more. In this respect the saola resembles the Rupicaprini (subfamily Caprinae), such as the serow, rather than other Bovinae. Dung et al. (1993) inferred from their data that male saola have longer and more divergent horns than females but our measurements do not support this assumption (Table 1). 
With which tribe in the Bovinae is the saola most closely aligned? Dung et al. (1993) tentatively placed the saola with the Boselaphini because it resembles the nilgai in some characters, such as the preorbital glands and the white markings of the pelage. Based on preliminary DNA analyses, the phylogenetic position of saola can be interpreted in two ways (P. Arctander and J. Gatesy, pers. comm.). Analysis of mitochondrial genes indicates that saola branched from Bovinae stock after the nilgai but before the Bovini and Tragelaphini split into distinct tribes. But nuclear gene analysis indicates that the saola and the Bovini split into separate evolutionary lines after first the nilgai and then the Tragelaphini had done so. A detailed analysis of skull and tooth characters could help determine whether the saola's closest affinity lies with the wild cattle or represents 'a rather deep branch of the subfamily', as Dung et al. (1993) phrased it, but we unfortunately had no access to a complete skull. However, some of the saola's features that we examined are indicative.

The preorbital gland is found widely among ruminants and is generally considered to be a primitive feature. Although only the nilgai and saola among the living Bovinae have this gland, it has also been observed in fossil Tragelaphini (E. Vrba, pers. comm.). A variable pattern of white markings on head and body is found not just in nilgai and saola, a comparison stressed by Dung et al. (1993), but also in the Tragelaphini, with some, such as bushbuck Tragelaphus scriptus and bongo Taurotragus euryceros, also having a white band above the hoof (Estes, 1991). Indeed, mountain anoa also have white above the hooves and on the face. But in its combination of these features - preorbital gland, white markings and a narrow, antelope-like muzzle - the saola most closely resembles the nilgai and Tragelaphini. However, some of the saola's skull characters show an affinity to the Bovini. The frontal sinus of saola extends well into the base of the horn cores, a characteristic of the Bovini that is either not found in the other Bovinae or is present only in rudimentary form. Furthermore, the first incisor among the Tragelaphini is considerably larger than the others, whereas among the Bovini the incisors are of roughly equal size (E. Vrba, pers. comm.). We have not examined saola teeth, but the rather imprecise drawings in Dung et al. (1993) conveys a Bovini pattern. In its body conformation and the shape of its hooves and horns, the saola is similar to the anoas, the most primitive living Bovini. These various characters suggest that saola belongs at the base of the Bovini clade before the lowest modern bovines evolved, as indicated also by nuclear gene analysis. However, the saola represents a startling combination of primitive morphological features retained from its antelope ancestry and of Bovini traits: it looks somewhat as if the head of an antelope has been attached to the body of a small buffalo. Given its unique characteristics, the saola may belong to a separate tribe within the Bovinae.

\section{Behaviour}

Male and female saola are usually solitary, according to local people who have seen or shot them. We have three reports of one of a pair of adult animals being killed; twice the dead animal was said to be a male and once a female. Other pairs consist of a female with young. Up to four saola together were reported to us, and Anon. (1993) gave a maximum group size of six/seven. Most Bovinae are gregarious, although adult males of all species may at times be solitary. The saola's grouping pattern most closely resembles that of anoa (Grzimek, 1984), bushbuck and sitatunga Tragelaphus spekei (Estes, 1991), all species favouring dense vegetation types.

Three reports of killings during December 1993 involved young accompanying mothers. One young had horns $9.5 \mathrm{~cm}$ long, another an estimated $15 \mathrm{~cm}$ and the third $18.8 \mathrm{~cm}$. This variation in horn length suggests a birth season extending over at least $2-3$ months, with births probably starting around the onset of the south-west monsoon in May. Various other ungulates that occur in the Annamites, such as serow, sambar Cerous unicolor, barking deer Muntiacus muntjak and wild pig Sus scrofa also give birth mainly late in the dry season or 
early part of the rains, at least in nearby Myanmar (Burma) and Thailand (Tun Yin, 1967; Lekagul and McNeely, 1988).

When chased by dogs, saola are said to run into the nearest stream and there make a stand with horn tips lowered and pointed at the dogs. One hunter showed us the site where a female had squatted in a stream with her rump against a boulder and her forelegs stiff as she faced the dogs. Retreat to a stream perhaps evolved as a defense against the packhunting dhole Cuon alpinus, which occurs in the region. Davidar (1975) reported similar behaviour among sambar in response to dhole. Saola probably threaten conspecifics with lowered horns also, and circumstantial evidence suggests that they use their dangerous horns to spar with each other. The saola's skin is 1-2 $\mathrm{mm}$ thick over much of the body and up to 2.5 mm thick on the lower back. However, the dorsal part of the neck, back to a point between the shoulders has skin $5 \mathrm{~mm}$ thick; this area could serve as a dermal shield to deflect or absorb thrusts from the rapier-like horns.

\section{Conservation}

'A few hundred' saola survive in Vietnam (Dung et al., 1993) and perhaps a similar number in Laos. With its numbers low and range restricted, the saola is an endangered species and urgently needs to be designated as such in national legislation and international conventions. ${ }^{*}$ Vietnam increased the size of the $\mathrm{Vu}$ Quang Nature Reserve from 160 to $600 \mathrm{sq} \mathrm{km}$ after the saola was discovered there and plans to transform the area into a national park; two additional reserves will be established within the range of the species (Dung et al., 1993, 1994). Laos has saola within its NNTNBCA. The boundaries of this protected area may soon be extended $15 \mathrm{~km}$ north, to about $18^{\circ} 30^{\prime} \mathrm{N}$, to include more saola habitat. The species possibly occurs also in the $775-\mathrm{sq}-\mathrm{km}$ Hin Namnu Conservation Area along the Vietnam border, south of the NNTNBCA, if an old distribution record from this karst region is indicative. We plan to survey the northern Annamites for potential reserve sites.

But reserves alone will not assure the species a future. Hunting is extremely heavy in the Annamites of Laos. Most households have a single-shot rifle and some have an automatic weapon; ammunition is cheap and readily available. Fortunately, saola are rarely encountered unless driven from cover by dogs. More deadly are snare lines - fences of brush with snares at intervals in openings which may extend for hundreds of metres over slopes and ridges and catch small to medium-sized ungulates unselectively. Laos banned snaring within its protected areas in February 1994. Such hunting regulations need to be enforced not just among villagers but also among workers of timber concessions. One concession in the NNTNBCA recently built a road into the most remote part. Aware of the problem, the government assigned protection staff to the conservation area in early 1994.

Vietnamese hunters readily enter Laos, a problem that can be solved only by a joint effort of the two countries. The Vu Quang Nature Reserve and the NNTNBCA are contiguous, forming a large transfrontier forest region whose protection and management would be enhanced by co-operation between Vietnam and Laos. More such transfrontier reserves need to be established in the Annamites.

The mountain forests of the Annamites still contain almost their whole complement of species, with the possible exception of Rhinoceros sondaicus, which may now be extinct there. Hunting, logging and a rapidly growing agricultural population, which depends to some extent on forest resources, threaten not only the biodiversity of the region but also the integrity of this important watershed. Unless an extensive network of reserves with core areas unaffected by human activities is established soon, the Annamites will ultimately be degraded or denuded and the saola may vanish before the 100th anniversary of its scientific discovery.

\footnotetext{
${ }^{*}$ Pseudoryx nghetinhensis was placed in CITES

Appendix I in November 1994. Editor.
} 


\section{Acknowledgements}

Our work was done under the auspices of the Wildlife Conservation Society in New York and the Department of Forestry of the Lao People's Democratic Republic. For assistance in Vientiane we thank: Bonaphanh Phanthavong and Vene Vongphet, Department of Forestry; Klaus Berkmüller and Robert Dobias, Forest Resources Conservation Project; Stuart Chape, World Conservation Union; and Tomas Jonsson, Lao-Swedish Forestry Co-operation Programme. Soukhatha Vannalat and Vixai Panyavikit, Department of Forestry, Thakhek, collaborated with us in the field, as did Salisa Sathapanawath. Thomas Evans and Robert Timmins, Cambridge University, provided us with some data; John Gatesy, University of Arizona, and Peter Arctander generously gave us the results of their DNA analysis; and Elizabeth Vrba, Yale University, provided insights into the evolutionary history of Bovinae. To all these individuals and organizations we are deeply grateful.

\section{References}

Anon. 1993. Auf den Fersen des "Dschungel-Rinds". Geo, 7, 156-160

Davidar, E. 1975. Ecology and behavior of the dhole or Indian wild $\operatorname{dog}$ Cuon alpinus (Pallas). In The Wild Canids (ed. M. Fox), pp. 109-110. Van Nostrand Reinhold, New York.

Delacour, J. and Jabouille, P. 1931. Les Oiseaux de l'Indochine Française. Exposition Colonial Internationale, Paris.
Dung, V.V., Giao, P.M., Chinh, N.N., Tuoc, D, Arctander, P. and MacKinnon, J. 1993. A new species of living bovid fromVietnam. Nature, 363, 443-445.

Dung, V.V., Giao, P.M., Chinh, N.N., Tuoc, D. and MacKinnon, J. 1994. Discovery and conservation of the $\mathrm{Vu}$ Quang ox in Vietnam. Oryx, 28 (1), 16-21.

Estes, R. 1991. The Behaviour Guide to African Mammals. University of California Press, Berkeley.

Grzimek, B. 1984. Grzimek's Animal Life Encyclopedia, Vol. 13. Van Nostrand Reinhold, New York.

Legendre, S. 1936. Land of the White Parasol and the Million Elephants. Dodd and Mead, New York.

Lekagul, B. and McNeely, J. 1988. Mammals of Thailand. Darnsutha Press, Bangkok.

Lydekker, R. 1924. The Game Animals of India, Burma, Malaya and Tibet. Rowland Ward, London.

Nowak, R. 1991. Walker's Mammals of the World, 5th edn. Johns Hopkins Press, Baltimore.

Salter, R. 1993. Wildlife in Lao PDR, a status report. IUCN, Vientiane.

Stone, R. 1992. No ordinary ungulate. Science, 257, 742.

van Strien, N. 1983. A Guide to the Tracks of Mammals of $W$. Indonesia. School of Environmental Conservation Management, Bogor.

Tun Yin, U. 1967. Wild Animals of Burma. Rangoon Gazette, Rangoon.

George B. Schaller and Alan Rabinowitz, The Wildlife Conservation Society, 185th St and Southern Blvd, Bronx Park, New York, NY 10460-1099, USA. 